\title{
DPPH Scavenging, PRAP Activities and Essential Oil Composition of Edible Lathyrus ochrus L. (Cyprus Vetch, Luvana) from Cyprus
}

\author{
Kaan Polatoğlü, 2* , Seniha Arsal ${ }^{2}$, Betül Demirci ${ }^{3}$ and Kemal Hüsnü Can Başer ${ }^{3,4}$ \\ ${ }^{1}$ Department of Analytical Chemistry, Faculty of Pharmacy, Istanbul Kemerburgaz University, 34217 Istanbul, Turkey. \\ ${ }^{2}$ Department of Analytical Chemistry, Faculty of Pharmacy, Near East University, 10 Mersin/Nicosia, Turkey. \\ ${ }^{3}$ Department of Pharmacognosy, Faculty of Pharmacy, Anadolu University, 26470 Eskişehir, Turkey. \\ ${ }^{4}$ Department of Botany and Microbiology, Faculty of Science, King Saud University, 11451 Riyadh, Saudi Arabia.
}

\begin{abstract}
The essential oil of the aerial parts of edible Lathyrus ochrus $L$. was investigated by simultaneous GC, GC/MS analyses under the same conditions. Trace amount of oil $(0.01>\mathrm{mL})$ obtained by hydro distillation of $200 \mathrm{~g}$ fresh plants was trapped in $1 \mathrm{~mL} n$-hexane. Twenty components were detected representing $91.55 \pm 0.56 \%$ of the oil. The main components were phytol $49.39 \pm 0.44 \%$, hexadecanoic acid $20.64 \pm 0.89 \%$ and pentacosane $4.20 \pm 0.09 \%$. Essential oil solution (1\% oil: $n$-hexane) afforded similar DPPH scavenging activity $(9.28 \pm 1.30 \%)$ when compared with positive controls $\alpha$-tocopherol $(9.74 \pm 0.21$ $\%)$ and BHT $(7.79 \pm 0.26 \%)$ at the same concentrations. Antioxidant activity of the oil was determined using a new HPTLC-PRAP assay. The oil afforded two fold higher reducing activity of phosphomolybdenum complex $(594.85 \pm 5.14 \mathrm{AU})$ when compared with positive controls $\alpha$ - tocopherol $(271.10 \pm 2.86 \mathrm{AU})$ and BHT $(210.53 \pm 1.81 \mathrm{AU})$ at the same concentration.
\end{abstract}

Key words: Lathyrus ochrus, essential Oil, HPTLC-DPPH assay, HPTLC-PRAP assay, phytol

\section{INTRODUCTION}

Lathyrus species (Fabaceae) are well known edible plants which are cultivated or gathered from wild. Several Lathyrus species have been reported as food products. Edible Lathyrus species include L. ochrus, L. aphaca L., L. cicera $L$. and $L$. sativus $\mathrm{L}^{1-4)}$. However, only $L$. ochrus is cultivated in Cyprus as food product which is known with the local name "Luvana". Usually fresh leaves of $L$. ochrus are consumed in salads and the seeds are used as a soup ingredient ${ }^{4)}$. Other Lathyrus species that are edible could also be found on the island however their use as food products is not known. L. sativus is also cultivated in Cyprus but not used as food instead it is used as a livestock feed material.

Previously phytochemistry of many Lathyrus species have been reported. However there are only a couple of reports indicating the volatile and essential oil composition of this genus. Previously new flavonoids, flavonols, chalcones, pterocarpans, saponins as well as known sterols were reported from the extracts of $L$. aphaca, L. pratensis L., L. chrysanthus Boiss., L. cloranthus Boiss., L. nissolia (L.) Döll., L. odoratus L., L. sativus, L. palustris
L. var. pilosus LEDEB. and L. japonicus Willd. ${ }^{5-12)}$. Essential oil composition of $L$. rotundifolius Willd. and $L$. vernus $\mathrm{L}$. were also reported. The essential oil of the aerial parts of $L$. rotundifolius was reported to have germacrene and elemene type sesquiterpenes (Germacrene D 50.4\%; germacrene B 18.7\%; $\gamma$-elemene $9.5 \%$ ) in high amounts ${ }^{13)}$. The flower and stem oils of $L$. vernus reportedly contained high amounts of palmitic acid (34.2 - 35.3\%) and 1-octen3 -ol $(49.8 \%)^{14)}$. Floral volatiles of three different cultivars of $L$. odoratus were also investigated. Acyclic monoterpenes were reported as the main components with varying amounts for each cultivar $((E)$ - $\beta$-ocimene $22.9-46.5 \%$, linalool 16.6-26.2\%, nerol 3.3-10.1\%, (Z)- $\beta$-ocimene 2.3 $7.3 \%$, geraniol $4.5-6.5 \%)^{15)}$. Lathyrus species also afforded new primary metabolites including a new carbohydrate Lbornesitol ${ }^{16)}$ and amino acids $\alpha$-N-oxalyl-L- $\alpha, \beta$ diaminopropionic acid ( $\alpha$-ODAP), $\beta$ - $N$-oxalyl-L- $\alpha, \beta$ diaminopropionic acid $(\beta \text {-ODAP })^{17}$. The beta isomer of ODAP is the known cause of the neurodegenerative disease called "lathyrism". The disease is initiated with over-consumption of Lathyrus species that contain this amino $\operatorname{acid}^{18)}$.

\footnotetext{
*Correspondence to: Dr. Kaan POLATOĞLU, Department of Analytical Chemistry, Faculty of Pharmacy, İstanbul Kemerburgaz University, 34217 İstanbul, Turkey

E-mail: kaanpolatoglu@gmail.com / kaan.polatoglu@kemerburgaz.edu.tr

Accepted October 17, 2014 (received for review August 4, 2014)

Journal of Oleo Science ISSN 1345-8957 print / ISSN 1347-3352 online

http://www.jstage.jst.go.jp/browse/jos/ http://mc.manusriptcentral.com/jjocs
} 
The purpose of the present study is to identify the chemical composition of the essential oil of the popular food luvana ( $L$. ochrus) for the first time. We believe the information obtained on the chemistry of this species will be used to evaluate general safety and beneficial properties of this edible species in Cyprus. Additionally free radical scavenging and antioxidant activities of the essential oil were also evaluated in order to provide information on the medicinal properties of this legume. This research was conducted as a part of our research project on the phytochemistry and biological activity of edible Lathyrus species of Cyprus.

\section{EXPERIMENTAL}

\subsection{Plant Material}

Plant materials were collected during the flowering period in 18 March 2012 from a cultivated field in the Güzelyurt region - Cyprus. Voucher specimens have been deposited in the Herbarium of the Near East University (Voucher no. 6772), Cyprus. Plant materials were identified by Dr. Kaan Polatoglu.

\subsection{Isolation of the Essential Oil}

Aerial parts of the fresh plant material $(200 \mathrm{~g})$ were chopped into small pieces $(1 \mathrm{~cm})$ and hydro-distilled $(1000$ $\mathrm{mL} \mathrm{DDH}_{2} \mathrm{O}$ ) using a Clevenger apparatus for three hours. Plant material yielded an oil less than $0.01 \mathrm{~mL}$ which was trapped in $n$-hexane $(1 \mathrm{~mL})$ and dried over anhydrous $\mathrm{Na}_{2} \mathrm{SO}_{4}$.

\subsection{Analysis of the Essential Oil}

The essential oil analysis was done simultaneously by gas chromatography (GC) and gas chromatography-mass spectrometry (GC/MS) systems.

\subsubsection{GC-MS analysis}

The GC-MS analysis was carried out with an Agilent 5975 GC-MSD system. Innowax FSC column $(60 \mathrm{~m} \times 0.25 \mathrm{~mm}$, $0.25 \mu \mathrm{m}$ film thickness) was used with helium as a carrier gas $(0.8 \mathrm{~mL} / \mathrm{min})$. The GC oven temperature was kept at $60^{\circ} \mathrm{C}$ for $10 \mathrm{~min}$ and programmed to $220^{\circ} \mathrm{C}$ at a rate of $4^{\circ} \mathrm{C} /$ min, and kept constant at $220^{\circ} \mathrm{C}$ for $10 \mathrm{~min}$ and then programmed to $240^{\circ} \mathrm{C}$ at a rate of $1^{\circ} \mathrm{C} / \mathrm{min}$. Split ratio was adjusted at $40: 1$. The injector temperature was set at $250^{\circ} \mathrm{C}$. Mass spectra were recorded at $70 \mathrm{eV}$. Mass range was from $\mathrm{m} / \mathrm{z} 35$ to 450 .

\subsubsection{GC analysis}

The GC analysis was carried out using an Agilent 6890N GC system. The FID detector temperature was $300^{\circ} \mathrm{C}$. To obtain the same elution order with GC-MS, the simultaneous auto-injection was done on a duplicate of the same column applying the same operating conditions. Relative percentage amounts of the separated compounds were cal- culated from FID chromatograms. The results of the analysis was given in Table 1.

\subsubsection{Identification of components}

Identification of the essential oil and volatile components were carried out by comparison of their relative retention times with those of authentic samples or by comparison of their relative retention index (RRI) to series of $n$-alkanes. Computer matching against commercial(Wiley GC/MS Library, MassFinder 3 Library) ${ }^{19,20)}$, and in-house "Başer Library of Essential Oil Constituents" built up by genuine compounds and components of known oils, as well as MS literature data ${ }^{21,22)}$ was used for the identification.

\subsection{HPTLC-DPPH Scavenging Activity Assay}

DPPH scavenging activity of the essential oil was determined with our previous HPTLC-DPPH radical protocol ${ }^{23)}$. Stock solutions ( 5 and $10 \mathrm{mg} / \mathrm{mL}$ ) of the $1 \%$ essential oil (pure oil: $n$-hexane $\mathrm{v} / \mathrm{v}$ ), positive controls $( \pm$ ) $\alpha$-tocopherol, BHT (Alfa aesar, Karlsruhe, Germany) (1, 5 and $10 \mathrm{mg} / \mathrm{mL}$ ) and $\mathrm{DPPH}(0.1 \mathrm{mM}$ ) (Fluka Chemie GmbH, Buchs, Switzerland) were prepared with $\mathrm{CH}_{3} \mathrm{OH} .200 \mu \mathrm{L}$ of the sample solutions were mixed with $1000 \mu \mathrm{L}$ of DPPH solution as well as positive controls and sample free blank controls in $1.5 \mathrm{~mL}$ Eppendorf tubes and vortexed for 2 minutes. Samples were incubated $1 \mathrm{~h}$ in the dark at room temperature. Incubated samples $(2 \mu \mathrm{L})$ were applied to known positions in $\mathrm{x}, \mathrm{y}$ axis to an aluminum $60 \mathrm{~F}_{254}$ TLC Plate (Merck Darmstadt, Germany) with $5 \mathrm{~mm}$ band length using the TLC applicator system(CAMAG, Muttenz, Switzerland). After application of the samples and controls on the TLC; plates were scanned at $517 \mathrm{~nm}$ with a TLC Scanner (CAMAG, Muttenz, Switzerland) and absorbance of the bands were detected. The percentage of DPPH scavenging activity was calculated according to DPPH Scav. Act. $\%=\left[\left(\mathrm{A}_{\text {Control }}-\mathrm{A}_{\text {Sample }}\right) / \mathrm{A}_{\text {Control }}\right] \times 100$ formula. The results of the DPPH scavenging activity test were given as mean \pm standard deviation obtained from five parallel experiments. The results of DPPH scavenging activity were given in Table 2.

\subsection{HPTLC-PRAP (Phosphomolybdenum Reducing Anti- oxidant Power) Assay}

This new HPTLC-PRAP assay involves use of "TLC plate" as a "microplate" and the "TLC Scanner" as a "microplate reader". The test substances were applied on $\mathrm{x}$ and y dimensions on the TLC plate and densitometric measurement was achieved using the TLC-Scanner, similar to our previous protocol ${ }^{23)}$. The HPTLC-PRAP assay was based on a previously described spectrophotometric PRAP protocol $^{24)}$. The solutions of $10 \%(\mathrm{w} / \mathrm{v})$ phosphomolybdic acid (Aldrich, St. Louis MO, USA), 10, 5, $1 \mathrm{mg} / \mathrm{mL} 1 \%$ essential oil (pure oil: $n$-hexane $\mathrm{v} / \mathrm{v}$ ), positive controls: $\alpha$-topocherol(Alfa aesar, Karlsruhe, Germany) and BHT (Alfa aesar, Karlsruhe, Germany)was prepared. Methanol 
Table 1 The Essential Oil Composition of Lathyrus ochrus ${ }^{1}$.

\begin{tabular}{|c|c|c|c|}
\hline $\mathrm{RRI}^{2}$ & Compound & $\%^{3}$ & Identification $^{4}$ \\
\hline 1400 & Tetradecane & $0.25 \pm 0.01$ & $t_{\mathrm{R}}, \mathrm{MS}$ \\
\hline 1700 & Heptadecane & $0.12 \pm 0.03$ & $t_{\mathrm{R}}, \mathrm{MS}$ \\
\hline 1779 & $(E, Z)-2,4-$ Decadienal & $0.13 \pm 0.01$ & MS \\
\hline 1800 & Octadecane & $0.10 \pm 0.0$ & MS \\
\hline 1868 & (E)-Geranyl acetone & $0.21 \pm 0.02$ & MS \\
\hline 1955 & Neophytadiene isomer & $3.53 \pm 0.36$ & MS \\
\hline 1958 & $(E)$ - $\beta$-Ionone & $0.85 \pm 0.02$ & $t_{\mathrm{R}}, \mathrm{MS}$ \\
\hline 1992 & Neophytadiene & $1.35 \pm 0.13$ & MS \\
\hline 2041 & Pentadecanal & $1.56 \pm 0.03$ & $t_{\mathrm{R}}, \mathrm{MS}$ \\
\hline 2131 & Hexahydrofarnesyl acetone & $1.73 \pm 0.04$ & MS \\
\hline 2296 & Isophytol & $0.68 \pm 0.05$ & MS \\
\hline 2384 & 1-Hexadecanol & $1.02 \pm 0.03$ & MS \\
\hline 2500 & Pentacosane & $4.20 \pm 0.09$ & $t_{\mathrm{R}}, \mathrm{MS}$ \\
\hline 2509 & Methyl linoleate & $0.42 \pm 0.01$ & $t_{\mathrm{R}}, \mathrm{MS}$ \\
\hline 2583 & Methyl linolenate & $1.72 \pm 0.42$ & $t_{\mathrm{R}}, \mathrm{MS}$ \\
\hline 2622 & Phytol & $49.39 \pm 0.44$ & MS \\
\hline 2670 & Tetradecanoic acid & $1.99 \pm 0.06$ & $t_{\mathrm{R}}, \mathrm{MS}$ \\
\hline 2700 & Heptacosane & $0.58 \pm 0.0$ & $t_{\mathrm{R}}, \mathrm{MS}$ \\
\hline 2822 & Pentadecanoic acid & $1.08 \pm 0.12$ & $t_{\mathrm{R}}, \mathrm{MS}$ \\
\hline \multirow[t]{6}{*}{2931} & Hexadecanoic acid & $20.64 \pm 0.89$ & $t_{\mathrm{R}}, \mathrm{MS}$ \\
\hline & Alkanes & 5.25 & \\
\hline & Fatty acids + methyl esters & 25.85 & \\
\hline & Diterpenes & 54.95 & \\
\hline & Others & 5.50 & \\
\hline & Total & $91.55 \pm 0.56$ & \\
\hline
\end{tabular}

\footnotetext{
${ }^{1}$ The analysis were carried out in triplicate

${ }^{2}$ RRI Relative retention indices calculated against $n$-alkanes

${ }^{3} \%$ area \pm SD, calculated from FID data

${ }^{4}$ Identification method: $t_{\mathrm{R}}$, identification based on the retention times $\left(t_{\mathrm{R}}\right)$ of genuine compounds on the HP Innowax column; MS, tentatively identified on the basis of computer matching of the mass spectra with those of the Wiley and MassFinder libraries and comparison with literature data.
}

was used as the negative control. Phosphomolybdic acid solution $(200 \mu \mathrm{L})$ and samples $(200 \mu \mathrm{L})$ were mixed then incubated at $80^{\circ} \mathrm{C}$ for 30 minutes. After all of the samples and controls were cooled to room temperature they were applied $(2 \mu \mathrm{L}-5 \mathrm{~mm}$ ) on silica gel TLC plate(Precoated Silica gel 60 F254 0.2 mm aluminium TLC plate Merck, Darmstadt, Germany) with the help of TLC applicator (Linomat 5 - CAMAG, Muttenz, Switzerland). TLC plate was scanned at $600 \mathrm{~nm}$ with a TLC-Scanner (TLC-Scanner 3 - CAMAG, Muttenz, Switzerland). Absorbance of the each spot were detected with TLC densitometry as "Absorbance Unit" (AU) and increased absorbance of the reaction meant increased reducing power when compared to the negative control. The results of the PRAP activity test were given as AU mean \pm standard deviation obtained from five parallel experiments. The results of the PRAP activity test were given in Table 2.

\subsection{Statistical Analysis}

Analysis of variance (ANOVA) was applied on the data obtained from the HPTLC-DPPH and HPTLC-PRAP assay followed by the post hoc "Tukey's test". The results of this analysis are given as the mean \pm standard deviation followed by different letters which indicate compared results 
K. Polatoğlu, S. Arsal, B. Demirci et al.

Table 2 DPPH Scavenging \& PRAP Activity of L. ochrus Essential Oil ${ }^{1}$.

\begin{tabular}{cccccccc}
\hline & \multicolumn{3}{c}{ PRAP Activitiy (AU) } & \multicolumn{3}{c}{ DPPH Scavenging Activity (\%) } \\
\cline { 2 - 7 } Oil $^{2}$ & $\alpha$-tocopherol & BHT & Blank & Oil $^{2}$ & $\alpha$-tocopherol & BHT \\
\hline $10 \mathrm{mg} / \mathrm{mL}^{3}$ & $593.87 \pm 5.14 \mathrm{e}^{3}$ & $837.03 \pm 1.38 \mathrm{a}$ & $819.70 \pm 2.10 \mathrm{~b}$ & $48.43 \pm 0.341$ & $9.28 \pm 1.30 \mathrm{ef}$ & $89.13 \pm 0.54 \mathrm{~b}$ & $90.81 \pm 0.35 \mathrm{a}$ \\
$1 \mathrm{mg} / \mathrm{mL}^{4}$ & $266.73 \pm 5.08 \mathrm{~h}$ & $663.47 \pm 2.60 \mathrm{c}$ & $622.73 \pm 1.64 \mathrm{~d}$ & & $0.40 \pm 0.14 \mathrm{~g}$ & $89.66 \pm 0.30 \mathrm{~b}$ & $88.92 \pm 0.17 \mathrm{~b}$ \\
$0.5 \mathrm{mg} / \mathrm{mL}^{5}$ & $187.27 \pm 3.8 \mathrm{j}$ & $554.67 \pm 7.17 \mathrm{f}$ & $502.80 \pm 4.46 \mathrm{~g}$ & & $0.01 »$ & $60.15 \pm 0.38 \mathrm{c}$ & $45.36 \pm 0.54 \mathrm{~d}$ \\
$0.1 \mathrm{mg} / \mathrm{mL}^{6}$ & $71.27 \pm 1.14 \mathrm{k}$ & $271.10 \pm 2.86 \mathrm{~h}$ & $210.53 \pm 1.81 \mathrm{i}$ & & $0.01 »$ & $9.74 \pm 0.21 \mathrm{e}$ & $7.79 \pm 0.26 \mathrm{f}$ \\
\hline
\end{tabular}

${ }^{1}$ The results were given as the Absorbance mean \pm standard deviation of five parallel experiments. (The given Absorbances were obtained as the absorbance unit (AU) of a TLC densitometric measurement.

${ }^{2}$ The stock solutions of the oil are prepared by dilluting $1 \%$ (oil $/ n$-Hexane; $/ \mathrm{v}$ ) oil solution in methanol.

${ }^{3}$ The essential oil stock solution contains $100 \mu \mathrm{g}$ pure oil in $1 \mathrm{~mL}$.

${ }^{4}$ The essential oil stock solution contains $10 \mu \mathrm{g}$ pure oil in $1 \mathrm{~mL}$.

${ }^{5}$ The essential oil stock solution contains $5 \mu \mathrm{g}$ pure oil in $1 \mathrm{~mL}$.

${ }^{6}$ The essential oil stock solution contains $1 \mu \mathrm{g}$ pure oil in $1 \mathrm{~mL}$.

have significant differences $p<0.05$. Statistical analysis was performed with XLSTAT-2012.6.02 trial version(Addinsoft, NewYork, USA).

\section{RESULTS}

The essential oil was obtained from the fresh aerial parts of $L$. ochrus $(200 \mathrm{~g})$ with a very low yield $(<0.01 \mathrm{~mL})$. We have identified twenty components of the essential oil representing $91.55 \pm 0.56 \%$ of the oil. The largest portion of the oil was comprised diterpenes (54.95\%) including phytol $(49.39 \pm 0.44 \%)$, isophytol $(0.68 \pm 0.05 \%)$ and neophytadiene derivatives (neophytadiene, $1.35 \pm 0.13 \%$; neophytadiene isomer, $3.53 \pm 0.36 \%)$. Remaining portion of the oil was composed of alkanes (5.25\%) and fatty acids and their methyl esters (25.85\%) including hexadecanoic acid 20.64 $\pm 0.89 \%$, pentacosane $4.20 \pm 0.09 \%$, tetradecanoic acid $1.99 \pm 0.06 \%$ and methyl linolenate $1.72 \pm 0.42$.

In the present study DPPH scavenging and phosphomolybdenum reducing antioxidant power of the essential oil were also determined. The dilutions of the $1 \%$ essential oil (pure oil: $n$-hexane $\mathrm{v} / \mathrm{v}$ ), yielded significantly low $\mathrm{DPPH}$ radical scavenging activity when stock solutions with the same concentration were compared. Highest DPPH scavenging activity was observed at the highest concentration applied (10 mg/mL (corresponds to $100 \mu \mathrm{g}$ oil $/ \mathrm{mL})-9.28 \pm$ $1.30 \%$ ) which afforded tenfold lower activity than the positive controls. However, the exact concentration of the oil at the highest activity was $100 \mu \mathrm{g} / \mathrm{mL}$ which produced significantly similar results to $\alpha$-tocopherol at $0.1 \mathrm{mg} / \mathrm{mL}(100 \mu \mathrm{g} /$ $\mathrm{mL}$ ) with higher activity than the BHT at the same concentration.

Similar to the DPPH scavenging activity, the oil presented lower reducing activity in PRAP assay when compared with the positive and negative controls at the same concentration. The dilutions of the essential oil solution ( $1 \%$ oil: $n$-hexane) showed significantly lower activity than the posi- tive controls when the same concentration of the stock solutions were compared. Highest PRAP activity was observed at the application of the oil with the highest concentration $(10 \mathrm{mg} / \mathrm{mL}$ (corresponds to $100 \mu \mathrm{g}$ pure oil/ $\mathrm{mL})-593.87 \pm 5.14 \mathrm{AU}$ obtained by densitometric measurement at $600 \mathrm{~nm}$ ). The highest activity obtained from the oil solution corresponds to a higher activity than the activity obtained for BHT and $\alpha$-tocopherol at $0.1 \mathrm{mg} / \mathrm{mL}$ $(100 \mu \mathrm{g} / \mathrm{mL})$ application $(210.53 \pm 1.81$ and $271.10 \pm 2.86$ respectively).

\section{DISCUSSION}

Previous reports indicate monoterpenes and sesquiterpenes are the main components of Lathyrus essential oils ${ }^{13-15}$. However, the oil of $L$. ochrus contained common acyclic diterpenes phytol and neophytadiene derivatives as main components. L. ochrus oil therefore can be defined as a good natural source of phytol. Phytol have many potential industrial uses it could be used as a precursor in the synthesis of $\alpha$-tocopherol (Vitamin $\mathrm{E})^{25)}$ and phylloquinone (Vitamin K1 ${ }^{26)}$ as well as its use in production of cosmetics, fragrances and household cleaners ${ }^{27)}$. However when the phytol exist in food products a special care is required since the consumption of large doses of phytol by the patients with refrum's disease could manifest itself with ataxia, retinitis pigmentosa, anosmia, hearing loss and polyneuropathy. Refrum's disease patients cannot metabolize phytanic acid which is accumulated as a side product of the free phytol in the tissues ${ }^{28)}$. The phytol is also known to be toxic and has growth inhibitory effect in test animals ${ }^{29)}$.

The beneficial properties of phytol have also been reported. Phytol has been identified as the anticonvulsant principle of Lactuca sativus. Phytol was shown to inhibit succinic semialdehyde dehydrogenase (SSADH) which acts in the degradation of $\gamma$-aminobutyric acid (GABA), a major 
inhibitory neurotransmitter ${ }^{30}$. In vivo, anti-inflammatory ${ }^{31)}$ and antinociceptive ${ }^{32)}$ activities of pure phytol have also been reported. High phytol containing plant essential oils such as Cleome sp. were also evaluated for their toxicity against sweet potato weevil Cylas formicarius elegantalus and high insecticidal activity was reported ${ }^{33,34)}$.

The PRAP activity method employed in the antioxidant evaluations is a new method for HPTLC. It involves densitometric measurement of the samples on TLC plates using a TLC scanner which enables quantitative evaluation of the PRAP activity of the extracts, essential oils and pure compounds. The method uses the TLC plate like a microplate and TLC scanner like a microplate reader. This method enables quantitative PRAP evaluation of a number of samples on a single TLC plate.

A previous research reported radical scavenging activities of the pure phytol against hydroxyl and nitric oxide radicals and its prevention of thiobarbituric acid reactive species (TBARS) in vitro. Pure phytol was reported to produce high radical scavenging and antioxidant activity in the applied tests ${ }^{32}$. The oil showed high DPPH and PRAP activities suggesting their relationship with phytol content. However, other components of the oil may also be responsible for the observed activity.

\section{CONCLUSION}

L. ochrus afforded an oil rich in phytol(49.4\%). Phytol content in fresh plant material can then be estimated as ca. $2.5 \mathrm{mg} / 100 \mathrm{~g}$. Therefore, patients with refrum's disease should consider avoiding over consumption of $L$. ochrus in their diets. The amount of the toxic amino acid $\beta$-ODAP which causes neurodegenerative disease "Lathyrism" is not reported for $L$. ochrus. In our literature survey, we did not find any lathyrism cases related to $L$. ochrus consumption. However the unknown $\beta$-ODAP content together with the reported toxicity and growth inhibition of phytol ${ }^{29)}$ long term frequent consumption of $L$. ochrus should be avoided for adults and especially for children.

Due to the high phytol content the oil could also have beneficial anti-inflammatory, anticonvulsant and antinociceptive as well as insecticidal activities. The essential oil produced high antioxidant and similar radical scavenging activities when compared to the positive controls at the same concentrations. The observed activities were concentration dependent. The PRAP activity of the oil was determined with a new HPTLC-PRAP assay. The new assay allows rapid determination of the PRAP activity of a number of samples quantitatively on a single TLC plate.

Overall, the L. ochrus plant could be regarded as a good source for phytol but the safety on the consumption of this plant as food product should be evaluated. Therefore, a more detailed phytochemical investigation of the non-vola- tile portion of this plant is deemed necessary, and is the subject of our ongoing research.

\section{ACKNOWLEDGMENTS}

This research was financially supported by The Scientific and Technological Research Council of Turkey(TUBITAKTOVAG 1110138).

\section{References}

1) Dalby, A. Food in the Ancient World from A to $Z$. Routledge, New York, pp. 167 (2013).

2) Enneking, D. The nutritive value of grasspea (Lathyrus sativus) and allied species, their toxicity to animals and the role of malnutrition in neurolathyrism. Food Chem. Toxicol. 49, 694-709 (2011).

3) Cooper, M. R.; Johnson, A. W. Poisonous plants in Britain and their effects on animals and man. H. M. S. O. Publishing, London, pp. 146-148 (1984).

4) Viney, D. E. An illustrated Flora of North Cyprus. $2^{\text {nd }}$ ed., Koeltz Publishing, Koenigstein, pp. 222-227 (1994).

5) Akihisa, T.; Nishimura, Y.; Roy, K.; Ghosh, P.; Thakur, S.; Tamura, T. Sterols of three Leguminosae seeds: Occurence of $24 \alpha$-ethyl- $5 \alpha$-cholest-9 $(11)$-en-3 3 -ol and both C-24 epimers of 24-ethylcholesta-5,25-dien-3 $\beta$-ol. Phytochemistry 30, 4029-4032 (1991).

6) Fuchs, A.; De Vries, F. W.; Landheer, C. A.; Van Veldhuizen, A., Odoratol and Methylodoratol, two $\alpha$-hydroxydihydro-chalcone stress metabolites from Lathyrus odoratus. Phytochemistry 23, 2199-2201 (1984).

7) King, S. S.; Ahn, B. T.; Kim, J. S.; Bae, K. Lathyrus Saponin, a New Trisaccharide Glycoside from Lathyrus japonicus. J. Nat. Prod. 61, 299-300 (1998).

8) Markham, K. R.; Hammett, K. R. W.; Ofman, D. J. Floral pigmentation in two yellow-flowered Lathyrus species and their hybrid. Phytochemistry 31, 549-554 (1992).

9) Markham, K. R.; Hammet, K. R. W. The basis of yellow coloration in Lathyrus aphaca flowers. Phytochemistry 37, 163-165 (1994).

10) Reynaud, J.; Ismaili, A.; Jay, M. Flavonoid glycosides of Lathyrus pratensis (Leguminosae). Phytochemistry 20, 2052-2053 (1981).

11) Robeson, D. J., Ingham, J. L. New pterocarpan phytoalexins from Lathyrus nissolia. Phytochemistry 18, 1715-1717 (1979).

12) Udayama, M.; Ohkawa, M.; Yoshido, N.; Kinjo, J.; Nohara, T. Structures of Three New Oleanene Glucuronides Isolated from Lathyrus palustris var. Pilosus 


\section{K. Polatoğlu, S. Arsal, B. Demirci et al.}

and Hepatoprotective Activity. Chem. Pharm. Bull. 46, 1412-1415 (1998).

13) Tajbakhsh, M.; Khalilzadeh, M. A.; Dabiri, H. A. Volatile constituents of Lathyrus rotundifolius Willd. and Trifolium mazanderanicum Rech. F. Two Papilionaceae herbs growing wild in Iran. J. Essent. Oil Res. 20, 119-121 (2008).

14) Iskender, N. Y.; Yayli, N.; Yasar, A.; Coskuncelebi, K.; Yayli, N. Volatile Constituents of the Flower, Leaf and Stem of Lathyrus vernus (L.) Grown in Turkey. Asian J. Chem. 21, 6290-6294(2009).

15) Porter, A. E. A.; Griffiths, D. W.; Robertson, G. W.; Sexton, R. Floral volatiles of the sweet pea Lathyrus odoratus. Phytochemistry 51, 211-214(1999).

16) Ichimura, K.; Kohata, K.; Mukasa, Y.; Yamaguchi, Y.; Goto, R.; Suto, K. Identification of L-Bornesitol and changes in its content during flower bud development in sweet pea (Lathyrus odoratus L.). Biosci. Biotechnol. Biochem. 63, 189-191 (1999).

17) Harrison, F. L.; Nunn, P. B.; Hill, R. R. Synthesis of $\alpha$ and $\beta$-N-Oxalyl-L- $\alpha, \beta$-diaminopropionic acids and their isolation from seeds of Lathyrus sativus. Phytochemistry 16, 1211-1215(1977).

18) Grela, E. R.; Studzinski, T.; Winiarska, A. Lathyrism in people and animals. Medycyna Weterynaryjna 56, 558-562 (2000).

19) Koenig, W. A.; Joulain, D.; Hochmuth, D. H. Terpenoids and Related Constituents of Essential Oils. Library of MassFinder 3, Hamburg (2004).

20) McLafferty, F. W.; Stauffer, D. B. The Wiley/NBS Registry of Mass Spectral Data. J Wiley and Sons, New York (1989).

21) Joulain, D.; Koenig, W. A. The Atlas of Spectra Data of Sesquiterpene Hydrocarbons. EB-Verlag, Ham$\operatorname{burg}(1998)$.

22) ESO 2000, The Complete Database of Essential Oils. Boelens Aroma Chemical Information Service, The Netherlands (1999).

23) Polatoglu, K.; Demirci, F.; Demirci, B.; Gören, N.; Başer, K. H. C. Antibacterial Activity and the Variation of Tanacetum parthenium (L.) Schultz Bip. Essential Oils from Turkey. J. Oleo Sci. 59, 177-184(2010).

24) Falcioni, G.; Fedeli, D.; Tiano, L.; Calzuola, I.; Mancinelli, L.; Marsili, V.; Gianfranceschi, G. Antioxidant ac- tivity of wheat sprouts extracts in vitro: Inhibition of DNA oxidative damage. J. Food Sci. 67, 2918-2922 (2002).

25) Netscher, T. Synthesis of Vitamin E. Vitam. Horm. 76, 155-202 (2007).

26) Daines, A. M.; Payne, R. J.; Humphries, M. E.; Abell, A. D. The Synthesis of Naturally Occurring Vitamin K and Vitamin K Analogues. Curr. Org. Chem. 7, 1625-1634 (2003).

27) McGinty, D.; Letizia, C. S.; Api, A. M. Fragrance material review on phytol. Food Chem. Toxicol. 48, S59S63 (2010)

28) Wierzbicki, A. S. Peroxisomal disorders affecting phytanic acid $\alpha$-oxidation: a review. Biochem. Soc. T. 35, 881-886 (2007).

29) Steinberg, D.; Avigan, J.; Mize, C. E.; Baxter, J. H.; Cammermeyer, J.; Fales, H. M.; Highet, P. F. Effects of dietary phytol and phytanic acid in animals. J. Lipid Res. 7, 684-691 (1966).

30) Bang, M. H.; Choi, S. Y.; Jang, T. O.; Kim, S. K.; Kunon, O. S.; Kang, T. C.; Won, M. H.; Park, J.; Baek, N. I. Phytol, SSADH Inhibitory Diterpenoid of Lactuca sativa. Arch. Pharm. Res. 25, 643-646 (2002).

31) Silva, R. O.; Sousa, F. B. M.; Damasceno, S. R. B.; Carvalho, N. S.; Silva, V. G.; Oliveira, F. R. M. A.; Sousa, D. P.; Aragão, K. S.; Barbosa, A. L. R.; Freitas, R. M.; Medeiros, J. V. R. Phytol, a diterpene alcohol, inhibits the inflammatory response by reducing cytokine production and oxidative stress. Fund. Clin. Pharmacol. doi: 10.1111/fcp.12049(2013)

32) Santos, C. C. M. P.; Salvadori, M. S.; Mota, V. G.; Costa, L. M.; De Almeida, A. A. C.; De Oliveira, G. A. L.; Costa, J. P.; Sousa, D. P.; De Freitas, R. M.; De Almeida, R. N. Antinociceptive and Antioxidant Activities of Phytol In Vivo and In Vitro Models. Neurosci. J. 2013, ID 949542, 1-9 (2013).

33) Mc Neil, M. J.; Porter, R. B. R.; Williams, L. A. D.; Rainford, L. Chemical Composition and Antimicrobial Activity of the Essential Oils from Cleome spinosa. Nat. Prod. Commun. 5, 1301-1306(2010).

34) Mc Neil, M. J.; Porter, R. B. R.; Williams, L. A. D. Chemical Composition and Biological Activity of the Essential Oil from Jamaican Cleome serrate. Nat. Prod. Commun. 7, 1231-1232(2012). 